\title{
Wake Up and Live: \\ The Roots of Cosmopolitanism in Oriental Worldview
}

\author{
Reza A.A Wattimena \\ School of International Relations, President University \\ Email: reza.antonius@president.ac.id
}

\begin{abstract}
This article describes the roots of cosmopolitanism in Oriental worldview, especially in the Indian and Chinese worldview. The idea of cosmopolitanism is important to understand today. It is seen as an alternative solution for various conflicts with religious and cultural motives as background. Oriental civilizations developed the idea of cosmopolitanism through various philosophical teachings, such as Vedanta and Buddhism. Both of them are inherently meditative and cosmopolitan. They focus on insight on reality as it is, not reality as it is conceptualized by religion, philosophy or science. This insight deconstructs also the normal understanding of selfidentity and stimulates the rise of cosmopolitan awareness, which is inherently experiential. Without this experience and awareness, various theoretical reflections on cosmopolitanism will be useless.
\end{abstract}

Key words: cosmopolitanism, oriental worldview, self-identity, interconnectedness, "wake up”- enlightenment.

\begin{abstract}
Abstrak
Tulisan ini ingin menjelaskan akar dari pandangan kosmopolitanisme di dalam pandangan dunia oriental, terutama di dalam pandangan dunia India dan Cina. Konsep kosmopolitanisme amat penting untuk dipahami hari ini. Ia dilihat sebagai jalan keluar alternatif dari berbagai konflik yang menjadikan agama dan budaya sebagai latar belakangnya. Peradaban oriental mengembangkan pandangan kosmopolitanisme melalui berbagai ajaran filosofis, seperti Vedanta dan Buddhisme. Keduanya amatlah meditatif sekaligus kosmopolit. Mereka mencoba memahami kenyataan sebagaimana adanya, dan bukan kenyataan yang telah dikonsepkan oleh agama, filsafat maupun ilmu pengetahuan. Pandangan ini mendekonstruksi pemahaman umum tentang identitas diri, sekaligus mendorong lahirnya kesadaran kosmopolit yang berpijak pada pengalaman. Tampak kesadaran dan pengalaman, beragam pemahaman teoritik tentang kosmopolitanisme akan menjadi tak berguna.
\end{abstract}

Kata-kata kunci: kosmopolitanisme, pandangan dunia oriental, identitas diri, kesalingterkaitan, "bangun"pencerahan

The title of this article is taken from one of the song from Bob Marley: "wake up and live!" During the ongoing conflicts in various parts of the world, it has a deep message for humanity. "Life is one big road with lots of signs, yes! So when you riding through the ruts, do not complicate your mind: flee from hate, mischief and jealousy." It is a difficult thing to do. Various problems in the world arise because of the identity difference. On the more extreme cases, ongoing conflicts and tensions, such as in Syria, Israel, Palestine,
South China Sea and Korean Peninsula, see no end in sight. Social identities become a justification to hate another group and start a conflict, which often can take place years to come to an end. It is not an exaggeration to say that life in many places is full of hate, mischief and jealousy.

On the much smaller level, identity differences become a main cause for the breaking of relationships, racism and various forms of discriminations against particular groups in politics, economy and social life as a whole. These situations 
create new potential for conflicts and social tensions in society. Cosmopolitanism as a worldview offers an alternative solution for these challenges. It opens up deep questions about being human in this globalized and fast changing world. The word cosmopolitanism means literally a theory on citizens of the world. It begins on the notion of natural state of human being as citizens of the universe, before any social identities were added to it. It has various political, moral and economic implications, which are still relevant for the world in the beginning of $21^{\text {st }}$ century. (Fine, 2008) It is also embedded in various cultures.

One of the ancient cultures that have a notion of cosmopolitanism is Oriental culture, namely Indian and Chinese culture. This article will describe the idea of cosmopolitanism in Oriental worldview. At first, it will explain the concept of waking up, which is central in the Oriental worldview. (1) Then, it will go deeper to the characteristics of Oriental worldview. (2) This article will also touch the notion of cosmopolitanism in Vedanta tradition. (3) Some critical remarks will be given in the next part of the article. (4) A concluding remarks will finalize this writing. (5) This article is heavily indebted to the works of Alan Watts and Seung Sahn on the Oriental worldview, especially Vedanta and Zen
Buddhism, and also the writer's personal research in the previous years.

This writing uses two methods. The first method is conceptual phenomenology. It understands the essence of a certain concept as it is, without preexisting assumptions. (Wattimena, 2010) In this context, the object of the research is the concept of cosmopolitanism in Oriental worldview. The second method is historical criticism. The purpose of this method is to understand a phenomenon in the past, in this context the concept of cosmopolitanism in Oriental worldview, with critical thinking, namely the ability to ask question in front of seemingly obvious facts and true opinions. The art of critical thinking suspends all judgment until the data and arguments are clear enough to form analysis and judgments.

\section{To Wake Up}

Oriental worldview originally develops in the Asian continent, especially in India and China. In this context, Oriental means the eastern part of the world. Of course, there is bias in this definition, because the term east is defined by the people in Europe. (Said, 2003) However, with that in mind, this writing focuses on the worldview that developed in India and China, especially Vedanta and Buddhism. There are two unique characteristics in this 
view, namely they are inherently meditative and cosmopolitan. They transcend reason and social identities to get in touch with the reality as it is. This is why cosmopolitanism developed very early in these areas in compare to other civilizations. These views will spread also to east Asian, such as Korea, Japan, Mongol and Taiwan, and also to South East Asia, namely to Thailand, Myanmar, Vietnam, Malaysia and Indonesia.

The main point of Oriental worldview is to wake up. It starts from the basic understanding that most of the people in the world are asleep. (Watts, 1995) That is the reason why they have a false view about the nature of things, and fight one another over something irrelevant to life as a whole. Because most of the people are asleep, they have a wrong sense of identity that creates delusion and hallucination about the nature of things. The wrong sense of identity can be seen clearly the in the concept of "I" as something separated from the world as whole. "I,my,me" are the slogans of the day. People concerns only to fill these three things with pleasure, although that these efforts often sacrifice other people and other living being. The extension of these concepts is property. Buying means having something attach to the self-identity. (Marcel, 2007) There is a sense of attachment to things. These things are now become new reality, which takes big efforts to maintain often at the expense of other people or nature.

The false view of identity is manifested also in the view that "I" am my body. Everything inside my body is me, and everything outside is not me. This view is so common, and people never question the validity and coherence of this view. This is an old and deep habit, which influences people's behavior, even when they do not aware of it. This view ignores the basic fact of nature, namely interdependence. It means that everything depends on everything. There is cosmic network that binds every living being. Everything is one: part of this cosmic network. In the Oriental worldview, to wake up means to see the reality as it is, free from presumptions and prejudices that generate false view that leads to suffering and conflicts. To see the reality as it is means to see the cosmic network of interdependence between all things that create a sense of unity. This is the basic notion of cosmopolitanism in Oriental worldview.

This notion is often forgotten, because of habits of the mind in daily lives that define human merely as individual, which is trapped in the body. However, this sense of separateness, in reality, is an illusion. That is the basic notion of Oriental worldview. (Wattimena, 2015) This illusion exists, because of the way a person is being brought up in a certain culture with 
particular values and worldview. This certain way of life is later seen as the truth and never questioned with critical and enquiring mind. To wake up means to wake up from the dream of separateness that is embedded so deeply in the various cultures, especially modern culture. Critiques against this view of separateness exist in not only the Indian and Chinese culture, especially Buddhism, but also the in modern science, such as biology and physics. A thought experiment in the logic of modern science is necessary here.

The feeling of separateness can be understood also as the feeling of isolation. It means that a person feels that he or she is a form of consciousness that is locked up in the body. However, from the scientific point of view, it is impossible to see and understand human in such a way. Science defines human first as living being. This living being cannot be understood properly without the context of its natural and social environment. His or her actions are every second interconnected with the natural and social context. The small act of hearing is an act of interconnectedness between various sounds and voices that are exist at the same time. The small act of moving hand requires collaboration between energy, oxygen, various muscles, air, blood etc. that without this kind of complex collaboration, there is nothing can be done.
The same thing applies to the act of seeing. To see something means to see the thing with its background. In a correct and deep observation, one realizes that there is no exact separation between things with its backgrounds. They all create a view that needs to be understood holistically. Most of the people do not understand this point of view. They are stuck in the false notion of isolated and separated identity. In Indian worldview, this false view is called ignorance, or avidya. The root of this ignorance is false habits, namely the habits to understand the world in parts and separation, and the habit to ignore the context of background that defines a thing. (Hyon Gak, 2006) To understand the world in its parts means to rely too much on focus and concentration as tools for observation and achieve understanding. These tools are, unfortunately, the main tools of modern science to discover new knowledge. The paradox is that the things we think are helping us to understand the world are the things that hinder us to experience the reality as it is, namely the truth itself. (Wattimena, 2008)

Ignorance, in the Oriental worldview, can also be understood as a kind of selective attention. This happens often in the magic shows, when the magician directs the attention of the audience towards certain area, so he or she can perform the magic tricks. Selective attention, according to 
Alan Watts, is the action of focusing one's attention to certain object and at the same time ignores everything else, such as the background that give meaning to this object at the first place. This habit of the mind creates an impression that an object exists independently separate from everything. (Watts, 1995) However, this view based on the habit of the mind cannot be more far from reality. Watts wrote,

"So, we come to think that the figure exists independently of the background, but actually they go together. They go together just as inseparably as backs go with fronts, as positives go with negatives, as ups go with downs, and as life goes with death. You cannot separate it. Therefore, there is a sort of secret conspiracy between the figure and the background: They are really one, but they look different. They need each other, just as male needs female, and vice versa." (Watts, 1995)
The problem is that we ignore this basic fact of reality.

From the scientific point of view, especially biology, the behavior of certain animals cannot be understood separately from its environment. Both are inseparable. The same thing applies to human action. Every action receives its meaning from its context of environment. Singing is not just someone singing something, but it requires the existence of air, space and various other factors. Every explanation and description of human action always implies naturally the description of its context and environment. Therefore, a scientific theory cannot just describe an individual action merely as action, but as a field, namely the interconnectedness of factors, or simply, a network. Watts called this phenomenon as organism/behavior to emphasize this point. This notion has been proven scientifically. However, it is not yet become a part of mainstream point of view for most people. They still feel that they are a small individual that are trapped in their body.

The main point of Oriental worldview is to make people realize that they are the universe itself. This experience of unity in Buddhism is called enlightenment. As consequences of this experience, a person then experiences freedom and peace at the same time. These two factors are the basic ingredients of compassion and wisdom that arise naturally 
from the person itself. This experience changes also the notion of "I" or selfidentity. There is no "I" that exists in isolation and separateness. (Metzinger, 2014) There is no small me that is trapped inside the body. These wrong views are basically an illusion that is created by habits of the mind and socialization process. The best analogy to explain this point is the relation between wave and the ocean. Every wave is part of the ocean. Both cannot be understood separately. It is just like the action of one person that includes the whole humanity itself. A person can continue his or her role in society. However, they live with a particular awareness that this role is superficial and can always be changed.

\section{Oriental Worldview}

This experience of unity can be achieved, if a person can suspend his or her habits of the mind, namely thinking. Thinking as an activity of the mind is the fundament of philosophy, science and technology. It becomes the main tool and purpose of modern education. (Wattimena, 2016, Tentang Manusia...) The philosopher of ancient Greek emphasizes the importance of thinking as the basic for the sense of wonder, which is understood as the beginning of philosophy and science. In this sense, philosophy is the drive of human from within to satisfy his curiosity to make sense of everything through his act of reasoning, and the essence of reasoning is thinking itself. There are several general definitions of thinking. However, from all these definitions, there is one basic component, namely the act of creating various symbols, such as numbers, words and signs, to make sense of the real world, which exists before this creation of symbols.

To wake up, in the sense of enlightenment in Oriental worldview, is to understand that these symbols are not the reality. These symbols represent the reality for the sake of human understanding, but it is always different for the reality itself. Today, we understand philosophy, science and technology mainly as the use of thinking through creation and manipulating of symbols to make sense of the world. There is basic misunderstanding that the symbols representing the world are seen as the world itself. In this sense, the whole range of reality is reduced to merely symbols, words, numbers and concepts. This tendency is the root cause of the sense of isolation and separateness, which are the main obstacle of enlightenment in Oriental worldview, because human understands the whole reality through mere narrow and limited abstractions, which they are creating. In other words, philosophy, science and technology, without the ability to think critically on its basic assumptions, 
are the obstacles toward the creation of cosmopolitan awareness.

Modern philosophy and science are different fundamentally with the Oriental worldview, or some people might define it as eastern philosophy. In this sense, Oriental worldview, especially in India, can be understood as a comprehensive worldview of the universe as a support for human to wake up, or reach enlightenment. That is why this type philosophy is often also understood as religion. However, this notion is not fully correct. Religion is, according to Watts, basically a bond and rule of life. (Mann, 2005) This definition is coherence with the root of the word itself. In a way, Oriental worldview offers also rule of life. However, this rules do not come from a super being that is supposed to create the universe, but the rules are understood as a support to help people to wake up from the dream of separateness and isolation, which has root in ignorance and forgetfulness. A person can object to the rules and create their own rules of life, as long as these rules can help him or her to reach the stage of enlightenment. (Seung Sahn, 1997)

Traditional religions, or as we call it the Abrahamic religions, contains three fundamental aspects, namely creed, code and cult. (Watts, 1995) Creed is metaphysical explanations about the origins and nature of reality. It is supposed to be coming from God, which is the source of all things. Code is several rules of life that have to be followed accordingly to guarantee salvation from God. Cult is the group activities to worship God the creator with various mediums, such as music, rituals, etc. Human salvation, especially after life, can be guaranteed only if they follow these creed, code and cult wholeheartedly. Critical questions are forbidden, because they will disturb the stability and coherence of these three fundamental aspects. This demand of total surrender and obedience are the root of various contemporary problems in the world today. (Wattimena, 2012)

Oriental worldview, especially the one in India, cannot be understood as religion in this sense. It does not emphasize the importance of obedience. There is no single creator that demands to be obeyed as a payment for human salvation. However, Indian worldview develops several explanations about the origins and the nature of the universe, which is very different with the one in Abrahamic religions. There are three basic explanatory models on the origins of the universe world. The first one is political model, where God is seen as the king who not just creates the whole universe, but also commands it by his divine will. This model is deeply embedded in Abrahamic religions, such as Judaism, Christianity and Islam. God reveals this will and commands to the prophet that will pass it as rules of life to the people who wants to 
be saved. Indian worldview has different model explanations on the origins and the nature of the universe.

The other model, according to Watts, is called dramatic model. This model is also very influential in various civilizations in world history. In this model, God is not seen and the sole creator of the universe, but as some kind of actor in a play that continuously involves and influences the development of the universe. This is the Hindu model of creation. In this model, everybody is God in a mask. Through their choices and actions, they create the world. Social identities and various attributes are seen as masks for the real nature of human, namely God itself. God is the actor behind all the human actions that shape the world. This godly nature inside every human cannot be understood with concepts and symbols. It exists before all kinds of concepts and symbols. It is everywhere, and, at the same time, nowhere.

Another model of the origins of the universe is called the organism model. In this model, the whole universe is seen as a big organism that has no creator. An analogy can help to understand this model. Usually, the brain is seen as the main part of the human body. However, this is a wrong view. Brain cannot function without the support of other organs, such as nerve system, blood and digestion. Organism is a collection of networks that sustain itself through the action of working together of all parts. It has no beginning, and no end. It has no highest boss, and no servant. All parts function together to guarantee the stability of all systems. From this perspective, the political and drama model make no sense at all. This organism model is usually found in the Chinese worldview. (Lai, 2008) Although, several sects in Indian tradition see also the world with this model.

An organism has various systems. These systems are supported with various type of parts. They move and grows together as a whole. It has a pattern, although not in a sense that it has a main goal to be fulfilled. There is this sense of anarchy in organism. However, this anarchy has a fluid pattern and order that shape it. This view tries to understand the laws of nature as it is. The basic idea is that the nature is something that happening of itself without the existence of creator or manager. In the context of cosmopolitan worldview, this view is called the Dharma, or the way. (Polenski, 2012) It means the natural way of the reality as it is. To live with the Dharma as guidance is the foundation of cosmopolitan awareness, because it sees the whole universe as collection of networks that create unity. Separation and isolation are just illusion, which is created by ignorance and false notion of reality. This experience and insight of unity of all things 
becomes the bedrock of cosmopolitan awareness.

Oriental worldview, such as the one that are developed in India and China, uses the dramatic model and the organism model to explain the origins of the universe and the nature of reality. In this model, human is not required to have obedience to a certain deities or other form of Super-being. In this sense, Oriental worldview, which inspires the development of cosmopolitanism, can be seen as a way of life, which focuses on the act of changing the state of consciousness. That is the reason why contemporary theories of psychotherapy are deeply inspired by Oriental worldview, such as the mindfulness therapy, meditation, etc. (Kabat-Zinn, 2005) The basic motive are to change the depressed state of mind to a healthy one through various methods that are based on the Oriental wisdom. This act of changing the state of consciousness is a fundamental way to develop a cosmopolitan awareness.

The uniqueness of Oriental worldview is that it does not emphasize the individual perspective as the source of various sufferings and problems in the world. This individual perspective must be transcended through various systematic ways, so that people can understand the reality as it is, and not as they want it. In this sense, the focus of Oriental philosophy is to wake people up from hallucination that is created by habits of the mind, which are embedded deeply in the traditions and cultures. This hallucination takes form in the sense of separation and isolation between people. To wake up from the hallucination means to experience the unity of all living being across the universe. (Jäger, 2010) This experience is the bedrock of cosmopolitan awareness.

Cosmopolitan awareness is not merely a conceptual framework. It is more of an experience of unity, which can be achieved when a person directly undergoes radical transformation of consciousness. This awareness automatically destroys all sense of ego, and opens a new dimension to a person that experiences it. The small ego then automatically is vanished, and a new dimension of consciousness comes, namely the universal ego where a person experiences a direct unity with the universe. All theoretical reflections and description of various types of cosmopolitanism will be useless, when there is no direct experience of unity with the universe itself. It is like learning to swim by remembering all the history and theories of swimming, but never actually swim.

In various traditions in Oriental worldview, such as the tradition in India, China, Japan, Korea, Thailand and Indochina, the self is understood as something much bigger than individual self. The real self, from the perspective of this 
tradition, is the Self, namely the universe itself. Behind this argument, there is a very important thesis, namely the thesis of interdependence. Everything is connected with everything. There is no separation. In this sense, Oriental approach on life as a whole cannot be understood merely as a religion, but as ways of liberation. (Wattimena, 2015) The basic question is, liberation from what? The short answer is liberation from hallucination, or the wrong view about reality as a whole. This process liberation requires experiment and critical thinking, and less of obedience. These two qualities are also very important for scientific research. (Wattimena, 2011, Penelitian Ilmiah...) This wrong view on reality is not in itself evil. Sometimes, it is needed for a person to participate in the daily social life, which requires some superficiality. However, when there is too much illusion or wrong view, one can experience needless suffering that pushes him or her to the edge.

\section{Vedanta and Cosmopolitanism}

Cosmopolitan awareness wakes people up from the dream of separation and illusion, which are often created by blind attachment and obedience to certain particular social identities. This attachment to particular social identities can be manipulated for a certain political interest, which is taking profit from the existing social conflicts. In Hinduism, the dominant tradition in India, there is deep discussion on cosmopolitanism in Vedanta. Veda means to see, and anta means end. It is old documents from circa 1500 BC. One thing to be noted, that Hindu scholars do not maintain an exact record on their teachings. They have another perspective on time, namely to understand time as circular. It means that the whole reality is something that just happened again and again, repeating itself. What was happen will happen today and also in the future. Life in in the universe follows a certain repeating structure, which can be understood through intellectual and spiritual investigations.

The main sources of Vedanta are mainly orally transmitted during the period more than 1000 years. Because of this, many things are quite vague and require more interpretations, especially the parts that deal with symbolical manifestations of various forms of deities, rites and hymns. The essence behind these complex systems is Atman. It can be understood as the soul of the universe, or the supreme self. The whole reality is direct manifestation of this supreme self, including our lives. This understanding contributes directly to the basic idea of cosmopolitanism, that all living being is, essentially, the one and the same. All is the expression of one fundamental essence, namely Atman. It can be said, that the all Oriental worldview 
expresses this notion, but with some variations on the concepts and pattern of logic.

The notion of universal Self in Upanishad, part of Vedanta, is, according to my interpretation, quite radical. It is said that the whole universe is basically just one thing, namely the Self. All other things are just fragile and temporary appearances. These varieties of appearances are considered as maya, which can be understood as illusion that deceives the human mind. The source of evil and suffering is the mistake to see maya as truth. If everything exists is just an illusion, maya, the question stands: what is the reality then? In this Vedic worldview, the reality is identical with the truth itself. However, this reality as the deepest truth cannot really be expressed through words and concepts. This is the reason why they use the concept neti, neti, or not this, not this. There can be no positive description for the ultimate reality, or it will only be just empty and misleading concept. (Seung Sahn, 1994) The best possible word to express this notion is as “the unknown”. (Suzuki, 2006)

The unknown is not an object for scientific or philosophical research. It is not also directly connected to religion. If it can be contained in a concept or word, it must be wrong. If it can be understood to merely intellectual exercise, it also must be wrong. A person must transcend his or her intellectual understanding to not just get the meaning of the unknown, but to experience it as such. This experiential understanding has an ability to transform the consciousness of a person from a merely speck of dust in this gigantic unlimited universe to the universe itself. The awareness of "the unknown" as the essence of all living being in the universe is the deepest foundation of cosmopolitanism from the perspective of Oriental worldview, especially in Indian tradition. This awareness does not just change the whole understanding about being human, but also removes sufferings and ignorance that cause internal conflict inside the mind, and conflicts between people. (Wattimena, 2016, Ruang Hening...)

This line of thought opens up the question concerning self-identity. If there is no difference between a person and the whole universe, how can we define and understand the concept of self-identity? From the perspective of Vedic tradition, self-identity is everything that exists. There is an expression of this, namely tat tvam asi. It means that you are it, or you are that. Basically, this expression wants to emphasize the divine nature of every sentient being. Everything in this universe is basically the divine itself, or "the unknown". In this context, the divine cannot be exactly understood as God, which has the power to create and rule the universe. This 
concept of ruling God is foreign in Oriental worldview. It is better understood as the energy, which moves eternally, and during its movement, the whole universe is created gradually moment to moment. In short, it is the life energy, which moves inside everything in this universe. (Sadhguru, 2016) In front of this deep understanding of life and the universe, the cultural line and political borders, which separate us from each other and provide justifications for racism, hatred, prejudices and conflicts, are naturally gone, and the cosmopolitan awareness automatically arises. (Wattimena, 2016, Manusia Kosmopolis...)

\section{Critical Remarks}

The essence of cosmopolitanism in Oriental worldview is to experience the reality as it is, which is basically impermanent and interconnected. In the course of time, there are several things to consider concerning the practice of cosmopolitanism that is based on Oriental worldview. The first one is the danger of attachment to emptiness. (Seung Sahn, 1994) Cosmopolitan awareness wakes people up to the nature of the reality as it is, namely the unknown. However, the experience of the unknown can be easily identified as the experience of emptiness. This experience is so joyful, and people can easily be attached to it. Attachment to emptiness creates a sense of arrogance, which can lead to apathy towards the situations in the world. In short, a person who is attached to emptiness becomes selfcontent, and cuts all relationships with the world.

This attachment to emptiness leads to a kind of moral nihilism, where a person does not have a moral sense of right and wrong. In other cases, nihilism takes people to the place of no value, which is mistakenly taught as emptiness and peace. This situation creates a docile person, which does not have political awareness. This person lives without direction, values, or meaning. Any negative circumstances will drive this person to insanity or suicide. From another perspective, this kind of nihilism will also push people to fatalism. It means the tendency to surrender on everything that happens in the world without a glimpse of will and effort to do something. The outer appearance is same with apathy, but the inside structure of the mind is different.

The political consequence of these tendencies is extreme political pacifism. In a way, pacifism is compatible with the idea of peace. It restrains people from violence, except in the context of self-defense. However, violence, according to my opinion, is not in itself good or bad. It can be used for good as well as bad purpose. Attachment to emptiness, tendency towards nihilism and fatalism, will lead to extreme political pacifism. These factors must be 
73 Reza A. A. Wattimena Wake up and Live: The Roots of Cosmopolitanism in Oriental Worldview

considered carefully in the context of cosmopolitanism in Oriental worldview. These things will lead directly to political apathy, which plays a significant role in the creation of totalitarian government and the

\section{Conclusion}

"Wake up and live!!", this captures the main argument of this article. The essence of Oriental worldview is to wake people up from the dream of isolation and separateness between living beings in the universe. This notion is also the core of cosmopolitan awareness from the perspective of Oriental worldview. After waking up, people can experience a deep and sustainable peace in their hearts. This is also the bedrock for peace between social groups, and world peace as a whole, because there is no peace in the world, if people cannot find peace in their hearts. destruction of good governance. (Wattimena, 2016, Zwischen kollektivem Gedächtnis...)

This peace comes from the sense of unity not just between humans, but also between living beings in this universe. This sense of unity is an experiential one, which touches not just the intellectual understanding of human, but also existential dimension of all living beings. To wake up and live, in this sense, means to have this direct experience of unity. This is not a new theory of view about the world. It is developed very systematically by various thinker in ancient India and China. The world in $21^{\text {st }}$ century can learn a lot from these ancient civilizations. Never forget history! 
74 Reza A. A. Wattimena Wake up and Live: The Roots of Cosmopolitanism in Oriental Worldview

\section{References}

Fine, Robert, 2008, Cosmopolitanism, Routledge; London.

Hyon Gak, Wanting Enlightenment is a Big Mistake, Shambala, 2006.

Jäger, Willigis, Ewige Weisheit: Das Geheimnis hinter allen spirituellen Wegen, Kösel, 2010.

Kabat-Zinn, Jon, Coming to Our Senses, Hyperion, 2005.

Lai, Katryn, An Introduction to Chinese Philosophy, Cambridge, 2008

Mann, William E., Blackwell Guide to Philosophy of Religion, Blackwell, 2005

Marcel, Gabriel, Being and Having, Dacre Press, 2007.

Metzinger, Thomas, Der Ego-Tunnel: Eine neue Philosophie des Selbst: Von der Hirnforschung zur Bewusstseinsethik, Piper, 2014

Polenski, Hinnerk, Hör auf zu Denken, sei einfach Glücklich, Barth, 2012

Sadhguru, Inner Engineering: A Yogi's Guide to Joy, Random House, 2016.

Said, Edward, Orientalism, Penguin, 2003.

Seung Sahn, The Compas of Zen, Shambala, 1997.

Seung Sahn, Dropping Ashes on the Buddha: The Teachings of Zen Master Seung Sahn, Grove Press, 1994.

Suzuki, Shunryu, Zen Mind, Beginner's Mind, Shambala, 2006.

Wattimena, Reza A.A. (editor), 2010, Metodologi Penelitian Filsafat, Yogyakarta, Kanisius.

Wattimena, Reza A.A., Bahagia, Kenapa Tidak?, Maharsa, 2015.

Wattimena, Reza A.A., Filsafat Anti Korupsi, Kanisius, 2012

Wattimena, Reza A.A., Penelitian Ilmiah dan Martabat Manusia, Evolitera, 2011

Wattimena, Reza A.A., Ruang Hening untuk Perdamaian Dunia, dalam https://rumahfilsafat.com/2016/12 /19/ruang-hening-untukperdamaian-dunia/ 29 Desember 2016

Wattimena, Reza A.A., 2008, Filsafat dan Sains, Jakarta, Grasindo. 
75 Reza A. A. Wattimena Wake up and Live: The Roots of Cosmopolitanism in Oriental Worldview 